\title{
História da psiquiatria em Pernambuco e outras histórias
}

\section{Cláudio Duque}

"Este não é apenas um livro de memórias, tampouco é um estudo sobre a história da Psiquiatria em Pernambuco e no Brasil. $\mathrm{Na}$ realidade, busca ser um pouco de ambas as coisas”, adverte o autor no prefácio. Nessa dicotomia reside parte do mérito do livro e muito da sua deficiência. Trata-se de uma coletânea. São 33 capítulos de natureza variada, sem fio condutor claro ou mesmo uma precisa ordenação cronológica ou temática, o que dificulta o trabalho do leitor. Muitos estão incluídos nas “outras histórias”. Alguns são documentos, como quatro noticiários e programações de Congressos e de uma Reunião da SBPC, realizados no Recife, e três discursos de posse do autor. Há ainda um discurso de saudação do professor José Lucena, e um precioso "A psiquiatria pernambucana à luz de suas publicações”, pelo incansável professor e webmaster gaúcho Walmor Piccinini, com 786 referências bibliográficas.

Os nove primeiros capítulos são conferências e relatórios do autor sobre temas como "Conceito de Doença Mental” ou “Angústia do Final do Milênio" (apresentados em encontros científicos desde 1988), nos quais a perspectiva histórica sempre é abordada. Estes capítulos, juntamente com dois sobre "o adoecer e a morte" e "as alterações psicológicas do paciente senil”, sintomaticamente postados 
R E V I S T A

no final do livro, revelam o talento e a cultura do conferencista, bem como sua capacidade de reflexão diante do fato psiquiátrico.

Há doze capítulos sobre personalidades da psiquiatria, de Ulysses Pernambucano a Henri Ey, originariamente saudações, conferências e necrológios que, acertando a veia memorialística do autor, se constituem na parte mais interessante do livro. Uma das principais dificuldades de um historiador/ memorialista é separar, na abordagem dos fatos, a linha melódica dos ruídos ocasionais. O Prof. Othon tem sensibilidade para identificar o fato marcante e separá-lo dos factóides estéreis e distinguir, reverenciando-os, aqueles que significam daqueles que apenas aparecem. Mais ainda, apontar em cada um a dimensão histórica e a sua transcendência. Por isso, o seu livro está longe de ser regional, articulando-se com o discurso da psiquiatria brasileira.

A Escola do Recife, que o Prof. Salvador de Miranda Sá Jr. disseca com agudo instrumento na apresentação, espalhou, pelo pioneirismo, sua influência além dos limites regionais e nacionais. Basta dizer que aqui se desenhou um modelo de assistência não hospitalocêntrico, e foram criados o primeiro serviço preventivo de saúde mental do país, o primeiro serviço aberto autônomo de saúde mental e o primeiro Instituto de Psicologia, entre outras realizações que resistem ao tempo. Falava-se em "reforma da assistência aos doentes mentais" e privilegiava-se a terapia ocupacional. O Hospital da Tamarineira, sob o comando de Ulysses Pernambucano, era modelo na América Latina pela humanização e respeito às características pessoais dos ali internados. Isso tudo entre 1920 e 1935, décadas antes do primeiro antipsicótico e outras tantas dos antipsiquiatras carregarem essas bandeiras por curto período. Não seria demasiado dizer que a atual "Reforma Psiquiátrica”, no Brasil, bem que poderia se chamar "Retorno ao tempo de Ulysses".

Dois escritos do Prof. Tácito Medeiros, sobre os primórdios da psiquiatria pernambucana e sobre o Prof. Luiz Cerqueira são excelentes contribuições desse perito no assunto.

Esta coletânea não é uma história da psiquiatria pernambucana, mas contém uma contribuição à história da psiquiatria no Brasil. O Prof. Othon Bastos é um historiador nato. Agradam-lhe a biografia, a análise do processo e a identificação dos marcos históricos. A história da psiquiatria em Pernambuco ainda está por ser contada, quem sabe, pelo próprio Prof. Othon com sua escrita elegante e a habilidade para encontrar a palavra exata e a expressão perfeita. Afinal, verdade seja dita, este livro já é uma aproximação dessa tarefa. 